\title{
The Pandemic City: Urban Issues in the Time of COVID-19
}

\author{
Lina Martínez ${ }^{1, *(\mathbb{D})}$ and John Rennie Short ${ }^{2} \mathbb{D}$ \\ 1 Business School, Universidad Icesi \& POLIS, Cali 760031, Colombia \\ 2 School of Public Policy, University of Maryland, Baltimore County, MD 21250, USA; jrs@umbc.edu \\ * Correspondence: 1mmartinez@icesi.edu.co
}

check for

updates

Citation: Martínez, L.; Short, J.R. The Pandemic City: Urban Issues in the Time of COVID-19. Sustainability 2021, 13, 3295. https://doi.org/ $10.3390 /$ su13063295

Academic Editor: Marc A. Rosen

Received: 28 January 2021

Accepted: 12 March 2021

Published: 17 March 2021

Publisher's Note: MDPI stays neutral with regard to jurisdictional claims in published maps and institutional affiliations.

\begin{abstract}
Pandemics have shaped the way cities are planned and configured. Throughout history, cities have evolved to solve problems of sanitation, hygiene, and health access while providing space and opportunities for the urban dwellers. COVID-19 will have significant implications in the way cities are planned. This recent crisis highlights a number of issues. This paper looks at the context for the pandemic and then reviews studies and debates in four areas: transformations in the configuration of public spaces, transportation, urban connectivities, and urban economies. This pandemic, like other similar episodes in the past, is forcing us to rethink the nature of urban space and may be an opportunity to plan for safer, more sustainable cities.
\end{abstract}

Keywords: COVID-19; urbanism; cities; pandemics

\section{Introduction}

The paper seeks to address a basic question: What are the urban implications of COVID-19? This is a review article that surveys recent work on actual and possible urban change in the wake of the recent pandemic. The questions raised by this health crisis touch every possible aspect of the urbanized life: health access, education accessibility, public space, economic activity, connectivities, and social inequalities. The crisis raises issues of our experience in the urban space, social contact, and the way we create and maintain our relationships. In this paper, we consider only some of urban implications of this current pandemic. We survey papers produced in the last year that focus in on four areas of the pandemic city: public space, transportation, connectivities, and the urban economy. Due to its recency, only the shorter-term consequences are empirically verifiable. However, the extent of COVID-19 is promoting a broad discussion of the long-lasting implications of this pandemic in the urban realm. Nevertheless, since the longer-term consequences lie in the future, this paper is thus more of a speculative essay raising possibilities rather than asserting definite conclusions.

The paper is divided in three sections. First, in order to situate the current pandemic, we briefly address the issue of the historical relationship between pandemics and cities. Second, we examine the global urban context of the growing prevalence of diseases in the life of contemporary cities. Third, we survey recent writings that focus on the implications of COVID-19 on public space, transportation, connectivities, and the broad impact it has on the urban economy, particularly in the global south.

The paper is a review article that seeks to provide a summary of recent writings that speculate on the possible futures of the post-COVID city. It is more suggestive than definitive of possible future trajectories across a range of topics. We feel that this speculative approach provides a useful background discussion for the more specifically orientated and empirically guided papers of this special edition.

\section{Cities and Disease}

The current pandemic is a reminder that the history of cities is bound up with the history of disease. As dense concentrations of people living and working together, they 
are a target-rich environment for disease, virus transmission, plagues, and epidemics. There was an urban death penalty as earlier cities had high death rates. The desire to leave the city during epidemics was a constant theme. A plague in Florence in 1348 is the backdrop to Giovanni Boccaccio's Decameron. He tells the story of 10 young people who escape the city to live in a villa. To pass the time in their self-imposed quarantine, they tell stores to each other. It became the basis for Chaucer's Canterbury Tales and for countless variations in world literature, cinema, and television. In 1665, Isaac Newton was quarantined in his family farm far enough away from Cambridge to escape the bubonic plague. For academics working at home today, he set the bar very high. If Newton could invent calculus and develop the basis for the Newtonian world view while quarantined, it does raise the question of our own intellectual productivity during our enforced stay at home.

Urbanization is one of the great achievements of modern societies and a condition of social progress [1]. It is also an accelerant of infection diseases [2]. Cities as dense concentrations of people provide the ideal environment for the spread of contagious diseases. Cities throughout history have been shaped by pandemics and their consequences $[3,4]$. The city is a resilient entity, and each critical episode has presented an opportunity to shape and rethink urban planning to ensure health and hygiene, exhibiting a great capacity to evolve after critical episodes [5].

Epidemics and pandemics played an important role in urban history [6]. The creation of parks, promenades, and public squares in European cities, for example, were early attempts to provide safer urban spaces [7]. Perhaps the largest impact was the rise of the public health movement in the nineteenth and twentieth centuries [8]. Public health initiatives were attempts to deal with the cities as unhealthy places filled with of contagious and fatal diseases [9]. Cities became the testing ground for the development of public health. John Snow's 1854 mappings of cholera in the streets of London is a famous example [10]. Cities were engineered to provide clean water, remove garbage, and treat sewerage. For all intents and purposes, the modern city was reimagined, reengineered, and reconfigured to meet the threat of disease. The role of cities as independent political units responding to pandemics is well documented for the flu epidemic of 1918 [11-13] and for H1N1 [14,15]. Cities are shaped and will continue to be shaped by responses to infectious diseases.

\section{The New Global Urban Context}

The world is becoming more urban, and the world's rural population is estimated to peak in 2021, and thereafter all population growth will be in cities. Global urbanization with associated land-use conversion and increasing global connectivity is the backdrop of this and more recent pandemics. One study found that the destruction of the natural ecosystems increases the number of rats, bats, and other animals that harbor diseases [16]. The conversion of wild places eradicates the large species allowing more of the smaller animals, such as bats and rats, that carry the most pathogens. In the Anthropocene, we are exposed to more human-pathogen interactions and more cross-species spillovers. Over 60 percent of new infectious diseases come from wild animals. The extension of urbanization, in association with commercial agriculture, transforms the wild areas and increases the possibility of more new viruses, for which we have no immunity. Large cities surrounded by agricultural land-uses, particularly in tropical regions with higher mammal diversity, have higher probabilities for human emergent infectious diseases [2]. The COVID-19 pandemic reveals the zoonotic threat caused by land-use conversion of wildlands into farmland, pasture, and urban areas.

The connected nature of global urbanization is also an important contextual factor. Space-time convergence between urban areas has an impact on disease transmission. With more and quicker global travel between city hubs, local outbreaks turn more easily into epidemics that can turn into global pandemics. In the first two weeks of January 2020, there were 1300 flights from China to the US, depositing 380,000 people including 4000 who came direct from Wuhan. COVID-19 also arrived in the US from Europe. The devastating impact 
on New York City was most likely from an air passenger corridor from China to Italy to the U.S. [17]. The virus spread out from these global hubs to the surrounding areas. In many cities, it was the more affluent global travelers, the rich cosmopolitans, who brought the disease. In the city of Houston, for example, the virus came with international travelers, first impacted the white, affluent neighborhoods before moving onto the lower-income, minority communities [18]. A similar tale can be told for cities across the world [19].

Globalization has made international travel cheaper, easier, and more prevalent. Within months, perhaps weeks, of the first outbreak, the disease seeded and spread around the world. It unfolded against the backdrop of an urbanized world. The majority, 55\% of the world population, lives in cities [20]. Rapid urbanization is driven in part by the promise that urban centers offer better opportunities, jobs, quality of life, and access to better services and goods. The pandemic reverses the calculus to some extent. Cities are now dense congregations of people where the disease can spread quickly and effectively. Cities, once the hope of the future and of the global south in particular, are now platforms for the pandemic.

\section{COVID-19 and Its Urban Implications}

A novel respiratory disease was identified in the city of Wuhan in December 2019. It developed sometime between October and November 2019 when a bat coronavirus, perhaps combined with a pangolin virus, entered the human population, probably through people who were processing bat carcasses for traditional Chinese medicine. The virus was given the name of severe acute respiratory system coronavirus-2 (SARS-CoV-2). The disease it causes, a respiratory illness that can be fatal especially for those aged over 60 and for those with underlying health conditions, is known as COVID-19 [21,22]. It spread quickly, and by January 2020, it had infected over 96 million people and caused over 2 million deaths according to Johns Hopkins Coronavirus Resource Center. The mortality figures are probably severe underestimates given the inconsistent and variable coding of COVID-related deaths and the inability of countries with limited health access to detect the spread of the virus [23]. The virus also mutated into new more contagious strains.

COVID-19 is one amongst the many pandemics in recent history. Since the flu of 1918, at least eight pandemics with global social and economic effects have been documented [24]. Pandemics are part of the modern world. About 14 million people die annually because of a pandemic [25].

An obvious question: what are the urban implications of this health crisis? To answer this question, we review the literature on public space, transportation, connectivities, and the urban economy that were produced in the last year that seek to answer the question in both the immediate and more verifiable short term and the more speculative longer term.

\subsection{Urban Public Space}

The public space of cities is where people concentrate, mingle, and interact. Often prized as an important part of the convivial nature of cities, in a pandemic they become feared as places where contagion between strangers is more likely [26]. The closure of urban public spaces, one of the more dramatic responses to COVID-19, especially impacts third spaces - those places that are neither work nor home-such as barbershops, bars, cafes, gyms, and restaurants [27]. Their closure reminds us of the social importance of these third places. Anderson [28] in his study of Philadelphia, describes what he terms as the cosmopolitan canopy of the city that consists of islands of civility. These are particularly important in segregated cities where different people can come together albeit in fleeting and sometimes ephemeral interactions. The cosmopolitan city was ripped apart by the urban lockdown. Even as the lockdown weakens and these third places now reopen, they face the problems of social distancing and limitations on the size of clientele [29]. It is in the third places of cities where businesses face very difficult times, with many perhaps closing [30,31]. The longer-term impact may be in the form of less-crowded places with stricter controls over spacing distancing and limitations on direct human-to-human contact 
between strangers. The postpandemic city may be less convivial. The decline in the number and thickness of third places may lead to an increase in safety but perhaps at a loss of social and psychological intimacy.

It is clear that the postpandemic city will be faced with new design challenges in order to make cities safer [32], or at least the illusion of safety. Urban places may also become sites of theatrical displays to assuage the fears of customers and consumer. Just as with security in the age of terrorist threats, health safety measures may become another form of theatrical display in the city. Reducing overall density may not be all that effective. One study showed little relationship between density and COVID-related infections and deaths across 36 cities across the world [33]. A repurposing of cities may also involve a reassessment of long-established public spaces such as the quiet outdoor café, the less-used public park, the less-familiar haunts, and the more private part of the city. The redesign has redistributional consequences. Lower income groups for example may rely on urban public spaces for social gatherings more than the more affluent who may have more space at home and so public space closures may have a greater negative impact on the family and social interactions of the less affluent [34].

History has shown that pandemics can be a catalyst for building safer environments [35,36]. The design of safer public spaces is not new, but the application is highly uneven. This pandemic provides an opportunity to introduce safety and health criteria in urban planning and to turn impromptu initiatives into permanent changes in urban planning [37].

The layout of the contemporary city emerged long after the impact of previous epidemics and pandemics were long forgotten. In the past 30 years, there has been an emphasis on densely populated urban spaces, from crowded sports arenas to high-density pedestrianized areas. That was the old normal; postpandemic, the new normal will be more concerned with health impacts of density, hygiene, and the safety of urban public spaces. This is likely to become an embedded rather than a transitory condition as long as the risk of future pandemics remains high. The risk of future pandemics remains a real possibility. However, it is important to remember that this restructuring raises the issue of the right to the postpandemic city. The postpandemic city will not only be a public health issue but also a political concern about who gets to decide [38]. There is a need to reimagine and rebuild the city in a world where pandemics may become more prevalent due to globalization [39] and climate change [40].

\subsection{Urban Transportation}

COVID-19 has involved marked changes in urban transport. First, there was an initial steep decline of all road traffic as less people travelled to work either by private car or by public transport. The decline of car traffic has created an opportunity to reinforce the shift away from car-dominant cities. Busy car thoroughfares were quieted with less traffic and less demand for street parking. This has created an opportunity for a reimaging of urban public spaces away from the dominance of cars and car users toward greater emphasis on non-car spaces. Some city streets became "street eateries" as restaurants spilled out onto sidewalks to provide open-air socially distanced places. The transformation of busy streets into pedestrianized spaces allowed social distancing and reimagining of what city streets could and should be. With COVID-19 lockdowns vastly reducing the use of roads and public transit systems, many city authorities are taking advantage by closing streets to cars, opening others to bicycles, and widening sidewalks to help residents maintain the six-foot distancing [29]. Cities across the world such as Boston, Vienna, Oakland, México, Milan, and Bogotá are adding and widening bike lines [41-43]. This is a continuation of a previous trend that encouraged walking and bicycling. The postpandemic city may be a more walkable and bicycling city than could have been imagined prepandemic. While the shift away from cars was already taking place, the pandemic reinforced these trends.

Second, an important part of the city is public transport. One of the immediate impacts of the pandemic was a rapid and steep reduction in demand. People worked from home 
and were wary of densely packed urban transportations. The calculus changed. In general, public transport is perhaps cheaper than private transport, but in the pandemic city, it is seen as riskier. Health advice to avoid crowded, enclosed spaces, and time spent in close contact with other citizens - each a feature of a normally functioning transit system-has made passengers more skeptical to re-enter the public transit system [26]. This drastic loss of revenue is undermining the short- and even the longer-term financial health of urban transport authorities.

\subsection{Cities and Connectivities}

The global urban network is the neural network of globalization. Along this network flows capital, people, ideas, and practices. Of these four, it is the flow of people that is the most drastically affected by the pandemic. Tourist and business travel were initially suspended and then reopened to varying degrees [44]. To some extent, urban tourism may return, but business travel may fail to recover with a consequent knock-on effect on convention hotels, convention cities, and the business services sector that deal with international business travel. After months and perhaps years of online operations, the business, government, and nongovernment communities may find it less necessary to fund business travel, especially as conference call technology becomes more sophisticated.

There is also the broader argument that the pandemic signals if not the end of globalization, then at the very least a marked shift $[45,46]$. Many nation-states are preoccupied with tightening their borders and prioritizing the health of their citizens. To what extent this will continue postpandemic is a moot point. Some see the COVID-19 pandemic as reversing the links between globalization and urbanization, increasing the distance between countries and among people. These changes will make for a safer and more resilient world, but also one that could be less prosperous, stable, and fulfilling [47]. Others argue that the whole world is now so radically interconnected that retreat from globalization may be temporary but not permanent [48]. Others argue that this moment provides an opportunity for a reset, the opportunity to remake globalization and to harness globalization to a common purpose or face a retreat into isolationism and nationalism that will crash the world economy and increase international tensions $[49,50]$.

\subsection{Urban Economies}

\subsubsection{Will the City Survive?}

The pandemic has seriously affected urban economies and the lives of urban dwellers [51]. Some have argued that it undermines the economic necessity for cities. However, the death of the city is regularly predicted [52]. Like Mark Twain's premature obituary, it is greatly exaggerated. The city was thought to be redundant when the telephone was introduced and then the computer. What was the point of cities when people could communicate over the phone or by internet? Hadn't they lost their rationale? The future was imagined as a global village of electronic cottages. In fact, the future was giant metro areas and dense cities.

After 9/11, some even thought that the threat of terrorism would lead to the suburbanization of financial services and drift away from the city. In the decades that followed, New York City continued to grow and prosper as a global financial center, as did London.

Cities, at least some of them, will survive the pandemic for the same reasons they survived the telephone, internet, and terrorist attacks. There are powerful economic forces at work. There are major economic benefits to agglomeration in cities. As early as 1922, Alfred Marshall noted that in cities, the pools of skilled labor allow the transfer of information, knowledge, and skill. The presence of subsidiary industries provides common goods and services; and the geographic proximity facilitates face-to-face contact that leads to the maintenance of trust and the exchange of information [53]. These forces are even more powerful for the more dynamic sector of the economy, banking and financial services, advertising, and the vast range of cultural and creative industries that are in the business of ideas and the narration of information into knowledge [54]. 
This cognitive capitalism, as it has been called [55], is built around face-to-face contact as an efficient means of communication that helps solve incentive problems, facilitates socialization and learning, and provides psychological motivation. The cities of cognitive capitalism will bounce back. Those that have more routine industries may not. This is a trend that is already occurring across the US in the past thirty years as cities such as San Francisco, New York, and San Jose continued to grow while cities like Detroit, Buffalo, and Schenectady continued to falter. Manufacturing can be offshored; basic information processing can be done almost anywhere with an internet connection. However, turning information into knowledge and the ideas into products is best done in dense cities.

Cities are the perfect mechanism for finding out about new job opportunities and generating social ties. Even, in the dating market, cities widen and deepen the dating pool and extend the range of choice of partners, for both the one-night and the long-term commitment, because social interaction needs geographic proximity [56]. Despite the long tradition of antiurbanism that always sees the urban demise just around the corner, cities will also survive because they are our greatest invention [57]. They continue to be the best platform to deal with a range of problems from climate change to ensuring economic growth.

On the other hand, the offices and office buildings where much of the routine data information processing take place are more vulnerable to collapse. As online working becomes more common, more routinized, and more normal, the old office building filled with workers who could do much of their work at home may be a casualty of the pandemic. Some part of the commercial real estate market may never recover. Twitters' recent announcement for its worker to work from home indefinitely may be the first indication that commercial real estate, especially in expensive markets will experience a major collapse in value. One commentator sees the real estate price decline in positive terms. Pearlstein [58] argues that cities will emerge more livable and affordable. With a collapse in values, housing and office space will become less expensive. The downsizing of retail and commercial space will end the inflation in land values perhaps making them more affordable. They may also be a balancing out way from the higher priced cities as some office functions move to smaller cheaper cities. A revalorization of urban land markets may produce more affordable cities.

\subsubsection{Urban Poverty}

Cities are also sites of stark and growing inequalities, and these are reinforced as the pandemic cuts a more destructive swathe through the less wealthy and less powerful $[51,59]$. All the indications suggest a deepening of inequality as the wealthy face minor inconvenience, but the poorer face economic collapse [60]. The progress in the global urban south experienced in the past decade, in which cities advanced toward sustainability goals, inclusion, better governance, and poverty reduction, will be most likely cease or even reverse given the significant economic and political impact of the global crisis. Cities in lower-income countries are less prepared to face the heath crisis and economic aftermath of pandemics. The population in lower-income countries have higher malnutrition rates, present higher rates comorbidities, and the health system does not receive the same level of resourcing [61,62]. By 2017, per-person health spending in low-income countries was U\$ 41, while in high-income countries, the figure increased to U\$ 2937 [20]. In light of these deep inequalities and the magnitude of the global crisis created by COVID-19, cities will be different after this pandemic. Cities will experience the exacerbation of pre-existing problems [63].

The crisis of COVID-19 will have a pervasive effect on urban poverty and may create a new precarity in cities across the world and especially in the global south. Before the pandemic unfolded, the continued reduction of poverty was reaching a plateau. Between 2010 and 2015, world poverty — vastly concentrated in urban areas-decreased from 15\% to $10 \%$, but decelerated from 2015 to 2019 , with a reduction of only 1.8 percentage [51]. The United Nations estimations of the increase in poverty because of COVID-19 amounts to 
71 million people pulled back into extreme poverty, given the economic stagnation, job losses, and the decrease of about $40 \%$ remittances to low- and middle-income countries [51]. In Sub-Saharan Africa, estimates suggest that urban poverty will increase by 44 percent [64]. The increase in poverty with the resultant negative impacts on health, education, and food security will be among the most pressing issues in the post-COVID era.

\subsubsection{Informal Economy}

The informal economy is one of the pervasive characteristics of the global South [65]. Despite the constant government efforts to reduce informality, the informal sector represents $90 \%$ of total employment in low-income countries, $67 \%$ in middle-income countries, and $18 \%$ in high-income countries, accounting for over 2 billion workers worldwide [66]. One desired objective for achieving more sustainable societies is providing well-played, secure, and decent jobs to all often delivered through formal employment. The increase in formal employment is a means and an end. It represents higher taxation, which provides more government resources and reduces poverty, which translates into less welfare spending and higher spending on human capital [67-69].

Government goals across the global south of reducing the informal economy's size may be pulled back, in effect reversing the gains on poverty reduction. Informal workers may experience a new precarity of less job opportunities, poorer quality of employment, and income reduction. Moreover, this crisis may increase school dropout and child labor, perpetuating the poverty of poor-informal workers. The International Labour Organization estimates that the pandemic effects will increase the poverty of informal workers by $21 \%$, $52 \%$, and $56 \%$ in upper-middle, high-income, and lower-income countries, respectively [66].

Despite the negative factors associated with the informal economy, this sector makes cities livable, more flexible, and often is the only venue of employment for large segments of the population, and maybe one the sectors that will allow the economic reactivation post-COVID area. This pandemic could become a catalyst to rethink the role of the informal sector in the broad discussion of economic reactivation. Short [70], for example, argues the case for encouraging street vending to blunt some of the economic pain of the pandemic. Street vending enhances urban public spaces, and promoting street vending can generate employment, keep people safe, and create the vitality and comity that is the hallmark of the livable humane city.

\section{Conclusions}

In this analysis, we surveyed the literature related to the impact of the recent pandemic on public space, transport, connectivities, and economy. Our analysis faces several limitations. The most relevant is that the current crisis is still developing and the long term consequences are unknown. Another limitation deals with the availability of literature about the implications of COVID-19 in urban living. Most of the literature produced about this pandemic deals with public health issues.

Given these limitations, we were still able to how that the pandemic highlighted existing issues as well as new ones such as the urban preparedness for future pandemics. We noted some of the shorter-term implications and hinted at some of the possible longerterm implications for city design, city planning, and indeed city living. We do not know yet all the long-lasting effects of this pandemic and how it will transform cities in the future. However, we are already experiencing some transformations. There is evidence that cities are changing: the trend implemented in many cities to increase road space for bikers and pedestrian is showing that cities are transforming and building on existing trends and creating new ones because of COVID-19. The narrative of shared road space is not new, but the rapid adaptation of more walkable and sustainable cities may be accelerated by the pandemic. We do know that cities will experience deep transformations as inequalities within and between cities will be exacerbated in the short to medium term. The available evidence shows a significant impact of this pandemic on urban economies, including the informal sector that will have direct consequences on public 
finances, inequalities, and increased poverty. COVID-19 has forced us to rethink city living. This crisis will increase urban poverty especially in the global south and reinforce already marked social and economic inequalities, but it also represents an opportunity to rethink governance structures, provision of public services, data use, and citizen and community self-management [63]. There will be losses, but there are also opportunities to rethink cities. We should take the opportunity to reimagine a livelier, more interesting, and more equitable postpandemic city as we continue to make cities less vulnerable to pandemics in the future.

Author Contributions: Conceptualization, editing and writing were equally shared by the two authors. All authors have read and agreed to the published version of the manuscript.

Funding: This research received no external funding.

Institutional Review Board Statement: Not applicable.

Informed Consent Statement: Not applicable.

Conflicts of Interest: The authors declare no conflict of interest.

\section{References}

1. Guan, X.; Wei, H.; Lu, S.; Dai, Q.; Su, H. Assessment on the urbanization strategy in China: Achievements, challenges and reflections. Habitat Int. 2018, 71, 97-109. [CrossRef]

2. Santiago-Alarcon, D.; MacGregor-Fors, I. Cities and pandemics: Urban areas are ground zero for the transmission of emerging human infectious diseases. J. Urban Ecol. 2020, 6, juaa012. [CrossRef]

3. Latham, A. How 3 Prior Pandemics Triggered Massive Societal Shifts. 2020. Available online: https://theconversation.com/how3-prior-pandemics-triggered-massive-societal-shifts-146467 (accessed on 8 November 2020).

4. Shah, S. Pandemic: Tracking Contagions, from Cholera to Ebola and Beyond; Macmillan: New York, NY, USA, 2016.

5. Megahed, N.A.; Ghoneim, E.M. Antivirus-built environment: Lessons learned from Covid-19 pandemic. Sustain. Cities Soc. 2020, 61, 102350. [CrossRef]

6. Hays, J.N. Epidemics and Pandemics: Their Impact on Urban History; ABC-CLIO: Santa Barbara, CA, USA, 2005.

7. Grant, J. What Cities Can Learn from Lockdown About Planning for Life After the Coronavirus Pandemic. The Conversation. 2020. Available online: https:/ / theconversation.com/what-cities-can-learn-from-lockdown-about-planning-for-life-after-thecoronavirus-pandemic-136699 (accessed on 20 November 2020).

8. Brinkley, C. How Pandemics Have Changed US Cities-Often for the Better. The Conversation. 2020. Available online: https: / / tinyurl.com/yxu3v45v (accessed on 6 September 2020).

9. Osborne, J.B. Preparing for the Pandemic: City Boards of Health and the Arrival of Cholera in Montreal, New York, and Philadelphia in 1832. Urban Hist. Rev. Rev. d'Histoire Urbaine 2008, 36, 29-42. [CrossRef]

10. Johnson, S. The Ghost Map: The Story of London's Most Terrifying Epidemic and How it Changed Science, Cities and the Modern World; Penguin: New York, NY, USA, 2006.

11. Correia, S.; Luck, S.; Verner, E. Pandemics Depress the Economy, Public Health Interventions Do Not: Evidence from the 1918 Flu. 2020. Available online: https: / ssrn.com/abstract=3561560; https: / www.rand.org/blog/2020/04/why-covid-19-will-notstop-globalization.html (accessed on 28 November 2020).

12. Colvin, C.L.; McLaughlin, E. Death, Demography and the Denominator: New Influenza-18 Mortality Estimates for Ireland. No. 2020-04. 2020. Available online: https:/ /www.econstor.eu/handle/10419/218827 (accessed on 30 September 2020).

13. Navarro, J.A. Lessons From the 1918 Pandemic: A U.S. City's Past May Hold Clues. The Conversation. 2020. Available online: https: / / theconversation.com/lessons-from-the-1918-pandemic-a-u-s-citys-past-may-hold-clues-140519 (accessed on 15 October 2020).

14. Bell, D.M.; Weisfuse, I.B.; Hernandez-Avila, M.; Del Rio, C.; Bustamante, X.; Rodier, G. Pandemic Influenza as 21st Century Urban Public Health Crisis. Emerg. Infect. Dis. 2009, 15, 1963-1969. [CrossRef] [PubMed]

15. Hoffman, L.M. The return of the city-state: Urban governance and the New York City H1N1 pandemic. Sociol. Health Illn. 2013, 35, 255-267. [CrossRef] [PubMed]

16. Gibb, R.; Redding, D.W.; Chin, K.Q. Zoonotic host diversity increases in human-dominated ecosystem. Nature 2020, 584, $398-402$. [CrossRef] [PubMed]

17. Worobey, M.; Pekar, J.; Larsen, B.B.; Nelson, M.I.; Hill, V.; Joy, J.B.; Rambaut, A.; Suchard, M.A.; Wertheim, J.; Lemey, P. The Emergence of SARS-Cov-2 in Europe and North America Science. 2020. Available online: https://pubmed.ncbi.nlm.nih.gov/32 912998/ (accessed on 17 September 2020).

18. Long, S.W.; Olsen, R.J.; Chrstiansen, P.A. Molecular Architecture of Early Dissemination and Massive Second Wave of the SARS-Cov-2 Virus in a Major Metropolitan Area. mBio. 2020. Available online: https://www.medrxiv.org/content/10.1101/2020 .09.22.20199125v3 (accessed on 29 October 2020). 
19. Mooney, C.; Achenbach, J.; Fox, J. Massive Genetic Study Shows Coronavirus Mutating and Potentially Evolving Amid Rapid U.S. Spread. The Washington Post. 2020. Available online: https://www.washingtonpost.com/health/2020/09/23/houstoncoronavirus-mutations / ?arc404=true (accessed on 15 October 2020).

20. World Health Organization. Global Spending on Health: A world in Transition; World Health Organization: Geneva, Switzerland, 2020.

21. Zhang, J.; Litvinova, M.; Liang, Y.; Wang, Y.; Wang, W.; Zhao, S.; Wu, Q.; Merler, S.; Viboud, C.; Vespignani, A.; et al. Changes in contact patterns shape the dynamics of the COVID-19 outbreak in China. Science 2020, 368, 1481-1486. [CrossRef] [PubMed]

22. Shereen, M.A.; Khan, S.; Kazmi, A.; Bashir, N.; Siddique, R. COVID-19 infection: Origin, transmission, and characteristics of human coronaviruses. J. Adv. Res. 2020, 24, 91-98. [CrossRef] [PubMed]

23. Lau, H.; Khosrawipour, V.; Kocbach, P.; Mikolajczyk, A.; Ichii, H.; Schubert, J.; Bania, J.; Khosrawipour, T. Internationally lost COVID-19 cases. J. Microbiol. Immunol. Infect. 2020, 53, 454-458. [CrossRef] [PubMed]

24. Madhav, N.; Oppenheim, B.; Gallivan, M.; Mulembakani, P.; Rubin, E.; Wolfe, N. Pandemics: Risks, Impacts, and Mitigation. 2017, pp. 315-345. Available online: https:/ / elibrary.worldbank.org/doi/abs/10.1596/978-1-4648-0527-1_ch17 (accessed on 28 November 2020).

25. Thompson, R.N.; Thompson, C.P.; Pelerman, O.; Gupta, S.; Obolski, U. Increased frequency of travel in the presence of crossimmunity may act to decrease the chance of a global pandemic. Philos. Trans. R. Soc. B 2019, 374, 20180274. [CrossRef] [PubMed]

26. Sarkin, G. Cities at the Front Line: Public Space in the Time of the COVID-19 Pandemic; CIDOB: Barcelona, Spain, 2020. Available online: https: / / www.smithgroup.com/perspectives/2020/ cities-at-the-front-line-public-space-in-the-time-of-the-covid-19 -pandemic (accessed on 3 November 2020).

27. Low, S. How Cafes, Bars, Gyms, Barbershops and Other 'Third Places' Create Our Social Fabric. The Conversation. 2020. Available online: https:/ / theconversation.com/how-cafes-bars-gyms-barbershops-and-other-third-places-create-our-social-fabric-135530 (accessed on 20 November 2020).

28. Anderson, E. The Cosmopolitian Canopy: Race and Civility in Everyday Life; Norton: New York, NY, USA, 2011.

29. Holland, O. Our Cities May Never Look the Same Again After the Pandemic. 2020. Available online: https://www.cnn.com/ style/article/cities-design-coronavirus/index.html (accessed on 15 October 2020).

30. Dhindaw, J.; Mehta, P. Reconfiguring Public Spaces Within the New Normal. 2020. Available online: https://timesofindia. indiatimes.com/blogs/voices/reconfiguring-public-spaces-within-the-new-normal/ (accessed on 30 September 2020).

31. Stevens, N.; Tavares, S. Cities Will Endure, but Urban Design Must Adapt to Coronavirus Risks and Fears. The Conversation. 2020. Available online: https:/ / theconversation.com/ cities-will-endure-but-urban-design-must-adapt-to-coronavirus-risksand-fears-135949 (accessed on 12 September 2020).

32. Honey-Rosés, J.; Anguelovski, I.; Chireh, V.K.; Daher, C.; Konijnendijk van den Bosch, C.; Litt, J.S.; Sánchez, U. The impact of COVID-19 on public space: An early review of the emerging questions-design, perceptions and inequities. Cities Health 2020, 1-17. [CrossRef]

33. Adlakha, D.; Sallis, J. Why Urban Density is Good for Health—Even During a Pandemic. The Conversation. 2020. Available online: https:/ / theconversation.com/why-urban-density-is-good-for-health-even-during-a-pandemic-142108 (accessed on 30 September 2020).

34. Iveson, K. We Don't Know What We've Got Till It's Gone-We Must Reclaim Public Space Lost to the Coronavirus Crisis. The Conversation. 2020. Available online: https://theconversation.com/we-dont-know-what-weve-got-till-its-gone-we-mustreclaim-public-space-lost-to-the-coronavirus-crisis-135817 (accessed on 17 September 2020).

35. Nieuwenhuijsen, M.; Khreis, H.; Verlinghieri, E. The role of health impact assessment for shaping policies and making cities healthier. In Integrating Human Health into Urban and Transport Planning; Nieuwenhuijsen, M.J., Ed.; Springer: New York, NY, USA, 2019; pp. 609-624.

36. Sennett, R. Building and Dwelling: Ethics for the City; Farrar, Straus and Giroux: New York, NY, USA, 2018.

37. Thompson, A. More Cycleways, Streets to Shut, Foot- Paths Widened under NSW's COVID-19 Plan; The Sydney Morning Herald: Sydney, Australia, 2020. Available online: https://www.smh.com.au/national/nsw/more-cycleways-streets-to-shut- (accessed on 15 October 2020).

38. Thorpe, A. Reclaiming the streets? We Can All Have a Say in the 'New Normal' after Coronavirus. The Conversation. 2020. Available online: https://theconversation.com/reclaiming-the-streets-we-all-can-have-a-say-in-the-new-normal-aftercoronavirus-137703 (accessed on 20 November 2020).

39. Antràs, P.; Redding, S.J.; Rossi-Hansberg, E. Globalization and Pandemics; National Bureau of Economic Research: Cambridge, MA, USA, 2020.

40. Pinner, D.; Rogers, M.; Samandari, H. Addressing Climate Change in Post-Pandemic World. McKinsey Quarterly April. 2020. Available online: http:/ / acdc2007.free.fr/mckclimate420.pdf (accessed on 30 September 2020).

41. Armario, C. Bogotá Encourages Bicycle Use to Prevent COVID-19—San Diego Union-Tribune en Español. Associated Press. Available online: https://www.sandiegouniontribune.com/en-espanol/noticias/story/2020-0317/bogota-fomenta-uso-debicicletas-para-prevenir-covid-19 (accessed on 12 September 2020).

42. Bliss, L. Mapping How Cities Are Reclaiming Street Space. 2020. Available online: https://www.citylab.com/transportation/20 20/04/coronavirus-city-street-public-transit-bike-lanes-covid-19/609190/ (accessed on 15 October 2020). 
43. Combs, T. Local Actions to Support Walking and Cycling During Social Distancing Dataset. 2020. Available online: http: / / pedbikeinfo.org/resources/resources_details.cfm?id=5209 (accessed on 28 November 2020).

44. Higgins-Desbiolles, F. The End of Global Travel as We Know It: An Opportunity for Sustainable Tourism. The Conversation. 2020. Available online: https:/ / theconversation.com/the-end-of-global-travel-as-we-know-it-an-opportunity-for-sustainabletourism-133783 (accessed on 30 September 2020).

45. Appadurai, A. Coronavirus Won't Kill Globalization. But It Will Look Different After the Pandemic. 2020. Available online: https:/ / time.com/5838751/globalization-coronavirus/ (accessed on 3 November 2020).

46. Cohen, R. Why COVID-19 Will Not Stop Globalization. 2020. Available online: https://www.rand.org/blog/2020/04/why-covid19-will-not-stop-globalization.html (accessed on 12 September 2020).

47. Garrett, G. The Post-COVID-19 World Will Be Less Global and Less Urban. 2020. Available online: https://knowledge.wharton. upenn.edu/article/post-covid-19-world-will-less-global-less-urban/ (accessed on 28 November 2020).

48. Holden, R. Vital Signs: A Connected World Makes This Coronavirus Scarier, but Also Helps Us Deal With It. The Conversation. 2020. Available online: https:/ / theconversation.com/vital-signs-a-connected-world-makes-this-coronavirus-scarier-but-alsohelps-us-deal-with-it-131662 (accessed on 29 October 2020).

49. Faiola, A. The Virus That Shut Down the World. The Washington Post. 2020. Available online: https://www.washingtonpost. com/graphics/2020/world/coronavirus-pandemic-globalization/ (accessed on 30 September 2020).

50. Schifferes, S. Will Coronavirus Be the Turning Point for Globalization? The Conversation. 2020. Available online: https: / / theconversation.com/will-coronavirus-be-the-turning-point-for-globalisation-134739 (accessed on 3 November 2020).

51. Nations, U. The Sustainable Development Goals Report 2020. United Nations, 2020. Available online: https://unstats.un.org/ sdgs/report/2020/ (accessed on 28 November 2020).

52. Rogaway, P. Marshall McLuhan Interview from Playboy. 1969. Available online: https://web.cs.ucdavis.edu/ \{\}rogaway/ classes / 188/spring07/mcluhan.pdf (accessed on 29 October 2020).

53. Chen, K. Industrial Agglomeration. In International Encyclopedia of Geography; Wiley: Hoboken, NJ, USA, 2017; pp. 1-8. Available online: https: / / doi.org/10.1002/9781118786352.wbieg0380 (accessed on 30 September 2020).

54. Hutton, T.A. Cities and The Cultural Economy; Routledge: London, UK ; New York, NY, USA, 2016.

55. Boutang, Y.M. Cognitive Capitalism; Polity Press: Cambridge, MA, USA, 2011.

56. Bruch, E.E.; Newman, M.E.J. Structure of Online Dating Markets in U.S. Cities. Sociol. Sci. 2019, 6, 219-234. [CrossRef] [PubMed]

57. Glaeser, E. The Triumph of the City; Penguin: New York, NY, USA, 2011.

58. Pearlstein, S. Nor so Fast, Urban Exodus: Coronavirus Could Make New York and San Francisco Great Places to Live Again. The Washington Post. 2020. Available online: https:/ / www.washingtonpost (accessed on 30 November 2020).

59. Nations, U. World Social Report 2020: Inequality in a Rapidly Changing World. United Nations, 2020. Available online: https:// www.un.org/development/desa/dspd/wp-content/uploads/sites/22/2020/02/World-Social-Report2020-FullReport.pdf (accessed on 28 November 2020).

60. Dam, A.V.; Long, H. Moms, Black Americans and Educators Are in Trouble as Economic Recovery Slows. The Washington Post. 2020. Available online: https:/ / www.washingtonpost.com/business/2020/10/02/september-jobs-inequality / (accessed on 30 November 2020).

61. Brundage, J.F.; Shanks, G.D. Deaths from Bacterial Pneumonia during 1918-19 Influenza Pandemic. Emerg. Infect. Dis. 2008, 14, 1193-1199. [CrossRef] [PubMed]

62. Murray, C.J.; Lopez, A.D.; Chin, B.; Feehan, D.; Hill, K.H. Estimation of potential global pandemic influenza mortality on the basis of vital registry data from the 1918-20 pandemic: A quantitative analysis. Lancet 2006, 368, 2211-2218. [CrossRef]

63. De la Varga, O. COVID-19: A mirror for the urban world's contradiction. In Cities on the Frontline: Managing the Coronavirus Crisis; de Losada, A.F., Abdulah, H., Eds.; CIDOB Report \#5; Center for International Affairs: Barcelona, Spain, 2020.

64. Welsh, C. Humanitarian Aid in Sahelian Cities: Lessons for Long Term Food Security; Center for Strategic and International Studies: Washington, DC, USA, 2021. Available online: https://www.csis.org/analysis/humanitarian-aid-sahelian-cities-lessons-longterm-food-security (accessed on 30 September 2020).

65. Bonnet, F.; Vanek, J.; Chen, M. Women and Men in the Informal Economy: A Statistical Brief; International Labour Office: Geneva, Switzerland, 2019. Available online: http:/ / www.wiego.org/sites/default/files/publications/files/Women $\% 20$ and $\% 20 \mathrm{Men} \%$ 20in\%20the\%20Informal,20 (accessed on 28 November 2020).

66. International Labour Organization. COVID-19 Crisis and the Informal Economy Immediate Responses and Policy Challenges. ILO Brief. May 2020. Available online: https://www.ilo.org/wcmsp5/groups/public/---ed_protect/---protrav/---travail/ documents/briefingnote/wcms_743623.pdf (accessed on 30 November 2020).

67. Daniels, P. Urban challenges: The formal and informal economies in mega-cities. Cities 2004, 21, 501-511. [CrossRef]

68. Brown, A. Rebel Streets and the Informal Economy: Street Trade and the Law; Taylor \& Francis: London, UK, 2017.

69. Adom, K.; Williams, C.C. Evaluating the explanations for the informal economy in third world cities: Some evidence from Koforidua in the eastern region of Ghana. Int. Entrep. Manag. J. 2014, 10, 427-445. [CrossRef]

70. Short, J.R. Street Vendors Make Cities Livelier, Safer and Fairer-Here's Why They Belong on the Post-COVID-19 Urban Scene. 2020. Available online: https://theconversation.com/street-vendors-make-cities-livelier-safer-and-fairer-heres-whythey-belong-on-the-post-covid-19-urban-scene-141675 (accessed on 20 November 2020). 